\title{
Glacially mediated impacts of climate warming on alpine lakes of the Canadian Rocky Mountains
}

\author{
Rolf D. Vinebrooke, Patrick L. Thompson, William Hobbs, Brian H. Luckman, Mark D. Graham and \\ Alexander P. Wolfe
}

\section{Introduction}

Climate warming is having a more pronounced impact on temperature change in alpine and polar regions than on a global scale (Beniston 2006, LemKe ET AL. 2007). For the Cordillera region of North America, climate models predict that warming will increase with elevation, reaching its maximum at mid-northern latitudes (BRADLEY et al. 2004). Dendrochronological models have already shown that summer temperatures in the Canadian Rockies were anomalously warm during the $20^{\text {th }}$ century (LUCKMAN \& WILSON 2005).

Catchment features (e.g., glaciers) strongly influence the impacts of global warming on mountain lakes (THOMPSON et al. 2005, GuiLizzoni et al. 2006). Warmer alpine conditions may cause glacially fed lakes to become more turbid by amplifying the influx of rock flour (LEONARD \& REASONER 1999). Alternatively, certain lakes will likely become clearer as climate warming ablates small glaciers (DESLOGES 1994).

Global warming should exert contrasting impacts on primary production in alpine lake ecosystems depending on the presence or absence of glaciers (THOMPSON et al. 2005). Warmer temperatures are expected to suppress primary producers in glacially fed alpine lakes as increased inputs of turbid meltwater reduce underwater light availability and generate colder lake temperatures. In contrast, climate warming can hypothetically stimulate primary production in clear lakes by increasing the extent and duration of stratification (Austin \& Colman 2007), the number of thermal-degree days (longer and warmer ice-free seasons), and recycling of nutrients (STRECKER et al. 2004).

We tested for the effects of climate warming on total alpine phytoplankton abundance during glacial versus nonglacial periods by reconstructing the 400-yr long histories of 2 lakes located in the Canadian Rocky Mountains. Glacial activity was inferred from estimates of clastic sediment flux based on variations in loss-on-ignition (LOI) organic carbon levels (Desloges 1994, LeONARD \& ReAsoner 1999, BEIERLE et al. 2003). Total photoautotrophic abundance was quantified using high performance liquid chromatographic analysis (HPLC) of taxonomically diagnostic sedimentary algal and phototrophic bacterial pigments (VINEBROOKE \&
LEAVITT 1999). The relationship between total annual photoautotrophic abundance in each lake and climatic variation was examined by correlating sedimentary microbial pigment concentrations with dendrochronologically inferred summer temperatures (LUCKMAN \& WiLSON 2005).

Key words: climate warming, glaciers, mountain lakes, microbial pigments, paleolimnology

\section{Materials and methods}

Curator Lake $\left(52^{\circ} 48^{\prime} \mathrm{N} ; 117^{\circ} 52^{\prime} \mathrm{W}\right)$ and McConnell Lake $\left(51^{\circ} 35^{\prime} \mathrm{N} ; 115^{\circ} 59^{\prime} \mathrm{W}\right)$ are 2 remote fishless alpine lakes located along the eastern Front Ranges of Jasper and Banff National Parks, respectively. Curator Lake is situated at an elevation of $2232 \mathrm{~m}$ a.s.1., and has a surface area of 10 ha and maximum depth of $25 \mathrm{~m}$. McConnell Lake is located at $2271 \mathrm{~m}$ a.s.1., and is slightly smaller (9.4 ha) and deeper (maximum depth of $31 \mathrm{~m}$ ). Both lakes are situated in sheltered cirque valleys currently devoid of glaciers and predominated by extensive fields of moraine along with sparse patches of vegetation. Further, short wind fetch $(<300 \mathrm{~m})$ and emission of gaseous sulfides upon retrieval of sediment cores suggested the presence of mid-summer thermal stratification and hypolimnetic anoxia in both lakes.

Cores were collected from both lakes during August 2006 using a modified Kajak-Brinkhurst gravity corer to collect a continuous sediment record with an intact sediment-water interface (GLEW et al. 2001). Cores were sectioned at the site in $0.25 \mathrm{~cm}(0-10 \mathrm{~cm}), 0.5 \mathrm{~cm}(10-20 \mathrm{~cm})$, and $1 \mathrm{~cm}$ $(>20 \mathrm{~cm})$ increments into VWR sample bags (VWR, Mississauga, ON, Canada) using a high-resolution sectioning device. Samples were transported on ice back to the laboratory where they were stored at $-20^{\circ} \mathrm{C}$ until pigment analysis.

Microbial pigment concentrations were quantified using a standard reverse phase high pressure liquid chromatographic technique (Vinebrooke \& LeavitT 1999). Pigments were first extracted from freeze-dried sediments using an acetonemethanol solution. Extracts were then filtered $(0.2-\mu \mathrm{m}$ pore nylon), dried under $\mathrm{N}_{2}$, and reconstituted using a precise vol- 
ume of injection solution. Chromatographic separation was performed with an Agilent 1100 Series HPLC equipped with a Varian Microsorb-100 $\AA$ C18 column, and pigment detected using in-line diode array and fluorescence detectors. Pigment concentrations were quantified via calibration equations and an electronic spectral library constructed using standards purchased from DHI Water and Environment (Agern Alle 5, DK-2970 Hoersholm, Denmark). All concentrations are expressed as mass per gram organic matter $\left(\mathrm{mg} \bullet \mathrm{g}^{-1} \mathrm{OM}\right)$, which was determined by mass loss on ignition at $550{ }^{\circ} \mathrm{C}$ (Heiri et al. 2001). Chronostratigraphy of the cores was established through analysis of ${ }^{210} \mathrm{~Pb}$ (measured as ${ }^{209} \mathrm{Po}$ ) by alpha spectroscopy (APPLEBY et al. 2001). Calculation of ages is based on unsupported ${ }^{210} \mathrm{~Pb}$ inventories and the constant rate of supply (CRS) model (APPLEBY \& OLDFIELD 1978). Having established a constant mass sedimentation rate from the lead inventories, the lower portions of the cores were extrapolated to give an estimated age for the base of each core.

\section{Results and discussion}

Temporal variation in sedimentary organic content differed substantially between the 2 alpine study lakes (Fig. 1). Little variation in the relatively low organic content of the core from Curator Lake indicated that clastic input was constant and heavy for approximately 200 years prior to the mid-1800s (Fig. 1a). Thereafter, a steady rise in organic content occurred during the early 1900 s as witnessed by a sharp transition from light gray to brown sediments at the 4-cm depth interval. We interpret these results as evidence of the ablation of a small glacier within the catchment of Curator Lake during the early $20^{\text {th }}$ century. In contrast, organic content was higher and more variable in the core from the deeper McConnell Lake (Fig. 1b). The rapid decline and subsequent increase in organic content between the late 1800s and mid-1900s corresponded with a sharp transition from dark grayish to black sediments at $8 \mathrm{~cm}$ below the watersediment interface. We infer that glacial activity was more variable in the catchment of McConnell Lake and involved complete ablation by the mid-1900s. These results agree with declines in sediment yield in other lakes of the southern Canadian Cordillera where sediment flux was exhausted following glacier retreat from Little Ice Age maxima during the late 1800s (DESLOGES 1994).

Sedimentary pigment-inferred total photoautotrophic abundance increased substantially in both lakes during the $20^{\text {th }}$ century (Fig. 2). Whole-lake primary production in Curator Lake was attributable to algae, consisting primarily of chlorophyll $a$-containing cyanobacteria and
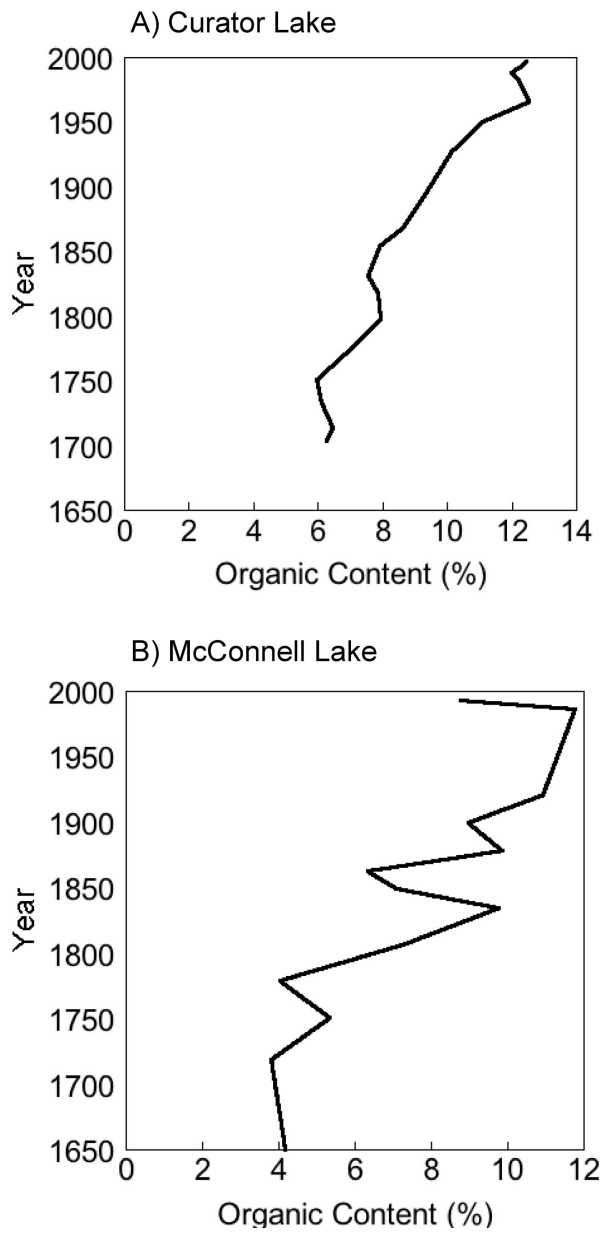

Fig. 1. Percentage organic content of accumulated sediment in (A) Curator Lake and (B) McConnell Lake as related to the ${ }^{210} \mathrm{~Pb}$-dated chronology.

chromophytes, such as chrysophytes, diatoms, and dinoflagellates (Fig. 2a). In contrast, the dramatic increase in total chlorophyll in a deeper McConnell Lake consisted primarily of bacteriochlorophylls (Fig. 2b) derived from planktonic, and also possibly benthic, green and purple sulfur bacteria (HuRLEY \& WATRAS 1991). These microbes thrive in anoxic deepwater habitats if underwater spectral irradiance is sufficient to sustain positive net photosynthesis. Therefore, we interpret these results as evidence of improved underwater light availability in both lakes following the decline of small local glaciers and their turbid inputs and longer ice-free growing seasons during a warmer $20^{\text {th }}$ century.

A warmer climate would also reduce vertical mixing (Austin \& Colman 2007) and promote deepwater anoxic conditions for phototrophic bacteria by increasing the thermal stability and stratification of McConnell Lake. Minimal variation by the pigment degradation index (total pheophytin- $a$ and pheophorbide- $a$ :total chlo- 
A) Curator Lake

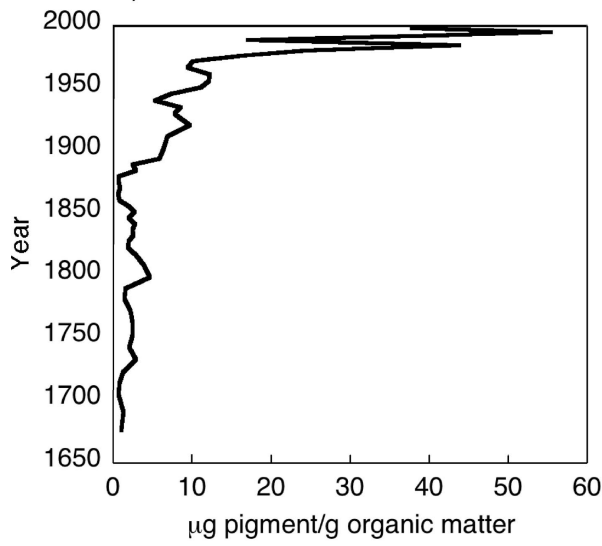

B) McConnell Lake

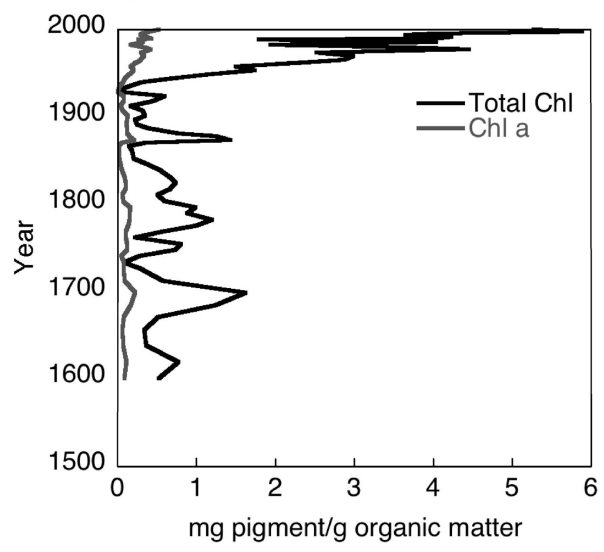

Fig. 2. Preserved sedimentary chlorophyll concentrations in (A) Curator Lake and (B) McConnell Lake as related to the ${ }^{210} \mathrm{~Pb}$-dated chronology.

rophyll-a) throughout both cores refutes the alternate explanation of these pigment profiles as being produced by diagenesis. In fact, our pigment-based inferences of increased pelagic primary production are supported by evidence from other measured paleo-proxies (i.e., stable isotopic carbon, diatoms) for both lakes (W. Hobbs, unpubl.).

Pigment-based estimates of whole-lake primary production were correlated positively with dendrochronologically inferred summer temperature anomalies (Fig. 3). The predictive relationship between annual summer temperature and total sedimentary chlorophyll content was significant $(r=0.48, p<0.001)$ for Curator Lake, but not McConnell Lake $(r=0.18, p=0.18)$. The more variable history of glacial activity in the McConnell catchment was a potential factor affecting the weak correlation between temperature and pigment concentration in the core. Specifically, periods of warmer temperature may have stimulated glacial melting, which would have actu-
A) Curator Lake

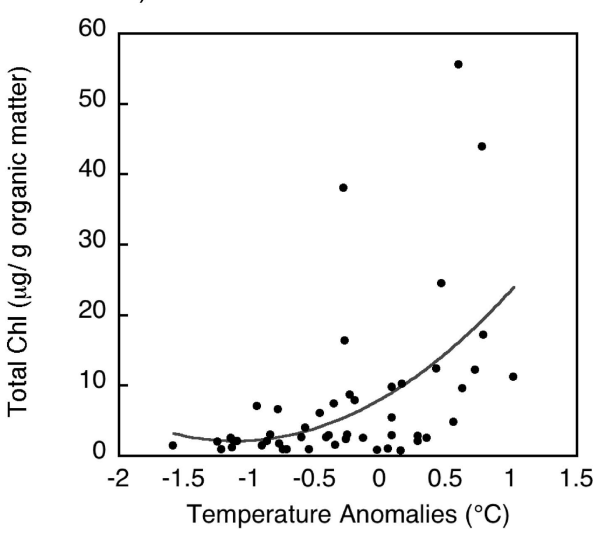

B) McConnell Lake

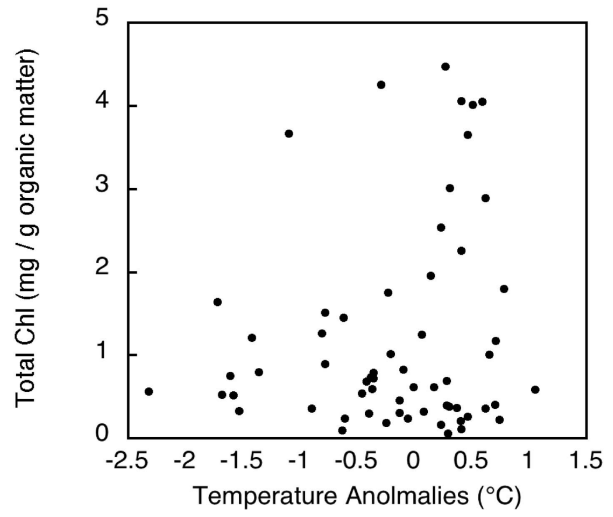

Fig. 3. Preserved sedimentary chlorophyll concentrations in (A) Curator Lake (significant regression line shown) and (B) McConnell Lake as functions of dendrochonologically inferred anomalies in summer air temperatures relative to the average for the $20^{\text {th }}$ century.

ally resulted in more turbid, colder, and less productive ice-free seasons in McConnell Lake. In Curator Lake, the impact of a warmer $20^{\text {th }}$ century on primary production would have been less confounded by the negative effect of cold, turbid meltwater given the possible earlier complete ablation of the small local glacier.

Our findings highlight the context dependency of the impacts of global warming on small alpine lakes. Local glaciers may dampen or even reverse the short-term decadal effects of warmer air temperatures on alpine lakes. However, the eventual complete ablation of small glaciers can amplify the impact of global warming on these ecosystems as they shift from a turbid coldwater condition to a clear and warmer state. For example, Thompson et al. (2005) reported that the epilimnetic temperature of ultra-sensitive alpine lakes can rise by $12{ }^{\circ} \mathrm{C}$ with an increase in air temperature of $6{ }^{\circ} \mathrm{C}$. Such a dramatic state change in alpine lakes would likely have a 
devastating effect on biodiversity as stenothermic species are eliminated, while immigration by tolerant species from warmer montane lakes is severely dispersal-limited (Holzapfel \& Vinebrooke 2005). Conversely, warming may increase certain alpine ecosystem functions (e.g., nitrogen fixation and phosphorus recycling) by enhancing enzymatic rates. Therefore, global warming could hypothetically shift alpine lakes toward a state for which there exists no post-glacial analogues.

\section{Acknowledgements}

This study was supported by grants awarded by the Alberta Ingenuity Centre for Water Research and the Natural Sciences and Engineering Council of Canada. Field assistance provided by Erin Doxsey-Whitfield, Suzanne McGowan, and Marie-Claire St. Jacques.

\section{References}

Appelby, P.G. \& F. Oldfield. 1978. The calculation of lead-210 dates assuming a constant rate of supply of unsupported ${ }^{210} \mathrm{~Pb}$ to the sediment. Catena 5: $1-8$.

ApplebY, P.G. 2001. Chronostratigraphic techniques in recent sediments, P. 171-203. In W.M. Last \& J.P. Smol [eds.], Tracking environmental change using lake sediments. Basin analysis, coring, and chronological techniques, vol. 1. Kluwer Academic, Dordrecht.

Austin, J.A. \& S.M. Colman. 2007. Lake Superior summer water temperatures are increasing more rapidly than regional air temperatures: A positive ice-albedo feedback. Geophysical Research Letters 34, L06604, doi:10.1029/ 2006GL029021.

Beierle, B.D., D.G. Smith \& L.V. Hills. 2003. Late Quaternary glacial and environmental history of the Burstall Pass area, Kananaskis, Alberta, Canada. Arct. Antarct. Alp. Res. 35: 391-398.

Beniston, M. 2006. Mountain weather and climate: A general overview and a focus on climatic change in the Alps. Hydrobiologia 562: 3-16.

Bradley, R.S., F.T. Keimig \& H.F. Diaz. 2004. Projected temperature changes along the American cordillera and the planned GCOS network. Geophys. Res. Lett. 31: L16210.

Desloges, J.R. 1994. Varve deposition and the sediment yield record at three small lakes of the southern Canadian cordillera. Arct. Alp. Res. 26: 130-140.
Glew, J.R., J.P. Smol \& W.M. Last. 2001 Sediment core collection and extrusion, p 73-106. In W.M. Last \& J.P. Smol [eds.], Tracking environmental change using lake sediments. Basin analysis, coring, and chronological techniques, vol. 1. Kluwer Academic, Dordrecht.

Guilizzoni, P., A. Lami, M. Manca, S. Musazzi \& A. Marchetto. 2006. Palaeoenvironmental changes inferred from biological remains in short lake sediment cores from the central Alps and Dolomites. Hydrobiologia 562: $167-191$.

Heiri, O., A.F. Lotter \& G. Lemcke. 2001. Loss on ignition as a method for estimating organic and carbonate content in sediments: reproducibility and comparability of results. J. Paleolimnol. 25: 101-110.

Holzapfel, A.M. \& R.D. Vinebrooke. 2005. Environmental warming increases invasion potential of alpine lake communities by imported species. Global Change Biol. 11: 2009-2015.

HuRLeY, J.P. \& C.J. Watras. 1991. Identification of bacteriochlorophylls in lakes via reverse-phase HPLC. Limnol. Oceanogr. 36: 307-315.

LeONARD, E.M. \& M.A. ReAsoner. 1999. A continuous Holocene glacial record inferred from proglacial lake sediments in Banff National Park, Alberta, Canada. Quat. Res. 51: 1-13.

Lemke, P., J. Ren, R.B. Alley et al. 2007: Observations: Changes in Snow, Ice and Frozen Ground, p. 367-389. In S. Solomon, D. Qin, M. Manning et al. [eds.], Climate Change 2007: The Physical Science Basis. Contribution of Working Group I to the Fourth Assessment Report of the Intergovernmental Panel on Climate Change. Cambridge University Press, Cambridge, UK and New York, NY, USA.

LuCKMAN, B.H. \& R.J.S. Wilson. 2005. Summer temperatures in the Canadian Rockies during the last millennium: a revised record. Clim. Dynam. 24: 131-144.

Strecker, A.L., T.P. Cobb \& R.D. Vinebrooke. 2004. Effects of experimental greenhouse warming on phytoplankton and zooplankton communities in fishless alpine ponds. Limnol. Oceanogr. 49: 1182-1190.

Thompson, R., C. KameniK \& R. Schmidt. 2005. Ultrasensitive alpine lakes and climate change. J. Limnol. 64: $139-152$.

VineBrooke, R.D. \& P.R. LeavitT. 1999. Phytobenthos and phytoplankton as potential indicators of climate change in mountain lakes and ponds: a HPLC-based pigment approach. J. N. Am. Benthol. Soc. 18: 15-33.

Authors' addresses: R. Vinebrooke, Freshwater Biodiversity Laboratory, Biosciences Centre, University of Alberta, Edmonton, Alberta, Canada T6G 2E9. E-mail: rolf@ualberta.ca

P.L. Thompson, M.D. Graham, Freshwater Biodiversity Laboratory, Biosciences Centre, University of Alberta, Edmonton, Alberta, Canada T6G 2E9.

W. Hobbs, A. Wolfe, Department of Earth and Atmospheric Sciences. University of Alberta, Edmonton, Alberta, Canada T6G 2 E3.

B. Luckman, Department of Geography, University of Western Ontario, London, Ontario, Canada N6A 5C2 